\title{
Выделение новых источников морозоустойчивости у сортов и гибридов винограда сложной генетической структуры
}
Владимир Владимирович Лиховской, д-р с.-х. наук, врио директора института, lihovskoy@gmail.com;
Али Алхазурович Зармаев, д-р с.-х. наук, профессор, зав. лабораторией генеративной и клоновой селекции, ali5073@mail.ru;

Валерий Анатольевич Зленко, канд с.-х. наук, доцент, вед. науч. сотр. лаборатории генетики, биотехнологий селекции и размножения винограда, vazlenko@mail.ru;

Ирина Александровна Васылык, канд. с.-х. наук, ст. науч. сотр. лаборатории генеративной и клоновой селекции, kalimera@inbox.ru;

Наталия Анатольевна Рыбаченко, науч. сотр. лаборатории генеративной и клоновой селекции, natalia.natikro@yandex.ru Федеральное государственное бюджетное учреждение науки «Всероссийский национальный научно-исследовательский институт виноградарства и виноделия «Магарач» РАН», 298600, Россия, Республика Крым, г. Ялта, ул. Кирова, 31.

\begin{abstract}
Направление выведения морозоустойчивых сортов винограда является актуальным и весьма трудным. Одним из важнейших этапов работы является выбор исходных сортов - доноров ценных признаков. Наиболее полные и достоверные сведения о морозоустойчивости сортов винограда можно получить только в результате полевых и лабораторных испытаний. Задачами исследований являлось определение степени морозоустойчивости новых столовых и технических сортов и гибридов винограда методом лабораторного промораживания, отбор наиболее перспективных сортов и гибридов для включения в селекционный процесс. В исследования включены 16 сортов и 28 гибридов. Согласно результатам проведенных исследований, среди группы бессемянных сортов наибольшая устойчивость к морозу отмечена у сорта Кишмиш аксайский: у более 40\% почек после промораживания при температуре минус $25^{\circ} \mathrm{C}$ развились побеги. Среди столовых сортов и гибридов наибольшая степень устойчивости $\mathrm{k}$ морозу отмечена у сорта Мускат Крыма: при температуре минус $24^{\circ} \mathrm{C}$ сохранность глазков остается на уровне $40 \%$, а при температуре минус $25^{\circ} \mathrm{C}$ - на уровне $14,3 \%$. В группе технических сортов высокую морозоустойчивость показал сорт Альминский - минус $26^{\circ} \mathrm{C}$ при полной сохранности глазков. Перспективным гибридом в этой группе стал Магарач № 8-08-8-4 (Кок пандас х Зейбель 6357), у которого при температуре минус $27^{\circ} \mathrm{C}$ отмечено прорастание побегов из 66,7\% замещающих почек и при температуре минус $26^{\circ} \mathrm{C}-50 \%$ из основных почек. В качестве источников морозоустойчивости выделены гибриды Магарач № 8-10-20-2 (минус $26^{\circ} \mathrm{C}$ ), Магарач № 530 (минус $27^{\circ} \mathrm{C}$ ) и Магарач № 512-243-1 (минус $27^{\circ} \mathrm{C}$ ). Исследования выполнены согласно ГЗ № 0833-2019-0006.
\end{abstract}

Ключевые слова: сорт; гибрид; морозоустойчивость; метод лабораторного промораживания.

\section{Как цитировать эту статью:}

Лиховской В.В., Зармаев А.А., Зленко В.А., Васылык И.А., Рыбаченко Н.А. Выделение новых источников морозоустойчивости у сортов и гибридов винограда сложной генетической структуры // "Магарач». Виноградарство и виноделие, 2019; 21(3); С. 186-190.

DOI 10.35547/IM.2019.21.3.001

How to cite this article:

Likhovskoi V.V., Zarmaev A.A., Zlenko V.A., Vasylyk I.A., Rybachenko N.A. Identification of new sources of frostresistance in grapevine cultivars and hybrids of complex genetic structure. Magarach. Vinogradarstvo $i$ vinodelie $=$ Magarach. Viticulture and Winemaking, 2019; 21(3):186 190. DOI 10.35547/IM.2019.21.3.001 (in Russian)

УДК: 634.84.09:631.524.86

Поступила 2.08.2019

Принята к публикации 20.08.2019

(C) Авторы, 2019
O R I G I N A L R E S E A R C H

\section{Identification of new sources of frost- resistance in grapevine cultivars and hybrids of complex genetic structure}

Vladimir Vladimirovich Likhovskoi, Ali Alhazurovich Zarmaev, Valeryi Anatolievich Zlenko, Irina Aleksandrovna Vasylyk, Nanalia Anatolievna Rybachenko

Federal State Budget Scientific Institution All-Russian National Research Institute of Viticulture and Winemaking Magarach of RAS; 31, Kirova Str., 298600, Yalta, Republic of Crimea, Russia.

Selective breeding of frost-resistant grapevine cultivars is a compelling and challenging task. One of the critical stages in this work is the selection of initial varieties that will become donors of valuable traits. The most complete and reliable data on frost resistance of grapevine cultivars can be obtained only as a result of field and laboratory tests. The purpose of the study was to determine frost resistance level of new table and wine grapevine cultivars and hybrids using laboratory freezing method, and select the most promising cultivars and hybrids for inclusion into the selection process. The study analyzed 16 cultivars and 28 grapevine hybrids. According to the data obtained in the course of the study, the highest frost-resistance among the seedless cultivars was demonstrated by 'Kishmish Aksaysky' grapes. More than $40 \%$ of the cuttings developed into plants after having been frozen at minus $25^{\circ} \mathrm{C}$ Among table cultivars and hybrids, the highest level of frost resistance was demonstrated by 'Muscat of Crimea' grapes. At minus $24^{\circ} \mathrm{C}$, $40 \%$ of the eyes were preserved, at minus $25^{\circ} \mathrm{C}-14.3 \%$ were preserved. In the group of wine cultivars, 'Alminsky' grapes demonstrated high frost resistance with complete eye preservation at minus $26^{\circ} \mathrm{C}$. 'Magarach № 8-08-8-4' ('Kok Pandas' $\mathrm{x}$ 'Zeybel 6357') became a promising hybrid in this group. At minus $27^{\circ} \mathrm{C}$, shoot sprouting constituted $66.7 \%$ from secondary buds; at minus $26^{\circ} \mathrm{C}-$ $50 \%$ from the main buds. As frost resistance sources, hybrids 'Magarach № 8-10-20-2' (minus $26^{\circ} \mathrm{C}$ ), 'Magarach № 530' (minus $27^{\circ} \mathrm{C}$ ) and 'Magarach № 512-243-1' (minus $27^{\circ} \mathrm{C}$ ) were singled out. The study was conducted within the framework of public assignment № 0833-2015-0015.

Key words: cultivar; hybrid; frost resistance; laboratory freezing method.

$\mathrm{B}$

ведение. В современном виноградарстве наибольшую популярность приобретают сорта, сочетающие ценные свойства европейско-азиатского вида (Vitis vinifera) и признак устойчивости к низким температурам от восточноазиатского ( $V$. amurensis) и американских видов $(V$. labrusca, $V$. riparia) [1-5]. ОАнако в большинстве своем возделываемые в промышленных насаждениях сорта винограда восприимчивы к морозу и грибным болезням [6-8].

На основе Алительной селекционной работы в Институте "Магарач" в рамках иммуноселекционной программы "Аналог" создан ряА сортов, обладающих устойчивостью к биотическим и абиотическим стресс-факторам биосферы в сочетании с высоким качеством продукции, - Подарок Магарача, Аанко, Спартанец Магарача, 
Цитронный Магарача, Ркацители Магарача и Ар. [9-12]. Отмечается высокая экономическая эффективность при возделывании этих сортов в различных виноградарских регионах Российской Федерации, Республики Молдова, Украины. Поскольку многие виноградарские регионы находятся в зонах рискованного виноградарства и возделывание классических европейско-азиатских сортов затруднено из-за их невысокой зимо- и морозоустойчивости, выбор сорта с учетом его генетических и биомогических свойств играет решающую роль в экономике виноградовинодельческой отрасли [11-13].

Сложность выведения высокоморозоустойчивых сортов объясняются тем, что признак морозостойкости обусловлен не специфическими генами, что характерно Аля Аругих признаков, а опредемяется генотипом растения в цемом [14]. Степень передачи признаков в значительной мере зависит от генотипов родительских пар и их комбинативной способности [9-11, 13, 15, 18]. Направление выведения морозоустойчивых сортов винограда является актуальным и весьма трудным. ОАним из важнейших этапов работы является выбор исходных родительских форм - доноров ценных признаков. Тестирование степени морозо- и зимостойкости сортов позволяет кмассифицировать их по группам устойчивости.

Наиболее полные и достоверные сведения о морозоустойчивости сортов винограда можно получить только в результате полевых и кабораторных испытаний [15-19].

Задачей наших исследований явмямось определение степени морозоустойчивости новых столовых и технических сортов и гибридов винограда методом мабораторного промораживания, отбор наиболее перспективных сортов ААя вкАючения в селекционный процесс.

Объекты и методы исследований. В исследования вкАючены 16 сортов и 28 гибридов винограда. Исследования выполнены согласно ГЗ № 0833-2019-0006.

$\Lambda$ абораторный метод заключается в промораживании черенков однолетних побегов винограда в низкотемпературных камерах. Температура изменяется по опредеценным программам дмя проведения закаливания с последующим тестированием морозоустойчивости. МетоА позволяет моделировать различный ход температурных режимов, который может скмадываться в естественных природных усмовиях, их перепады, скорость нарастания применительно к Аюбым климатическим условиям.

В исследовании был использован мабораторный метоА тестирования морозоустойчивости на основе методик Погосяна К.С. [20] и Черноморец М.В. [21]. Аиагностика морозоустойчивости у размичных сортов и гибридов винограда проводилась путем закаливания и промораживания Авухглазковых черенков вызревшей мозы: I фаза закаливания - плюс 8-плюс $4^{\circ} \mathrm{C}$ в течение 14 суток; II фаза закаливания - минус $3^{\circ} \mathrm{C}$-минус $5^{\circ} \mathrm{C}$ в течение 11 суток; III фаза закаливания - минус $10^{\circ} \mathrm{C}$ - сутки. Затем черенки поэтапно промораживами в интерваме температур от минус $16^{\circ} \mathrm{C}$ Ао минус $24^{\circ} \mathrm{C}$, с шагом изменения температуры $2^{\circ} \mathrm{C}$; от минус $24^{\circ} \mathrm{C}$ до минус $30^{\circ} \mathrm{C}$, с шагом $1^{\circ} \mathrm{C}$. После каждого из десяти последовательных этапов промораживания (минус $16^{\circ} \mathrm{C}-2$ суток; минус $18^{\circ} \mathrm{C}-3$ суток; минус $21^{\circ} \mathrm{C}-2$ суток; минус $24^{\circ} \mathrm{C}-2$ суток; минус $25^{\circ} \mathrm{C}-3$ суток; $26^{\circ} \mathrm{C}-2$ суток; минус $27^{\circ} \mathrm{C}$ -2 суток; минус $28^{\circ} \mathrm{C}-3$ суток; минус $29^{\circ} \mathrm{C}-2$ суток и минус $30^{\circ} \mathrm{C}-2$ суток) часть черенков каждого генотипа в количестве 5 переносили в холодильник с температурой плюс $2^{\circ} \mathrm{C}$ Аля их постепенного оттаивания в течение 3 суток. Затем черенки сутки вымачивали в воде и ставили на проращивание в полиитровые емкости с водой при комнатной температуре плюс $16^{\circ} \mathrm{C}-$ плюс $22^{\circ} \mathrm{C}$.

Морозоустойчивость генотипов винограда опредемяли после 4 недель их проращивания на воде оценкой процента развития побегов из почек после каждого этапа промораживания. Амя более объективной оценки жизнеспособности мозы после промораживания, дополнительно определяли Алину развившихся побегов, количество и Алину корней, а также развитие соцветий.

Обсуждение результатов. Согласно результатам проведенных исследованиий, среди группы протестированных бессемянных сортов наибольшая устойчивость к морозам отмечена у сорта Кишмиш аксайский, у более $40 \%$ черенков которого после промораживания при температуре минус $25^{\circ} \mathrm{C}$ развились побеги (рис. 1). Аругим перспективным сортом Аця использования в селекционном процессе при создании бессемянных гибридов может быть сорт Артек, устойчивость которого к морозу минус $24^{\circ} \mathrm{C}$ при сохранности глазков $33,3 \%$. Новый сорт винограда Крымский бисер характеризуется устойчивостью к морозу на уровне большинства европейских сортов - минус $21^{\circ} \mathrm{C}$, при этом полная сохранность глазков наблюдается мишь при температуре минус $18^{\circ} \mathrm{C}$.

Среди столовых сортов и гибридов наибольшая степень устойчивости к морозу отмечена у сорта Мускат Крыма - при температуре минус $24^{\circ} \mathrm{C}$ сохранность глазков остается на уровне $40 \%$, а при температуре минус $25^{\circ} \mathrm{C}$ - 14,3\%. Аругим перспективным гибридом столового направления использования явмяется Магарач № ТТ-2 (Тамисман х Томайский). При температуре минус $24^{\circ} \mathrm{C}$ из замещающих почек у $50 \%$ черенков наблюдается рост побегов. В этой группе сортов у сибсов Магарач № 19-11-4-19 и Магарач № 19-11-3-55 (Талисман колх. Х Асма) устойчивость к морозу фиксируется на уровне минус $21^{\circ} \mathrm{C}$ при сохранности глазков 75 и 50\% соответственно. У сибсов Магарач № 3-11-2-30 и Магарач № 3-11-2-41 (М.№31-7710 x 2000-305-143) устойчивость к морозам находится на уровне европейских сортов - минус $18^{\circ} \mathrm{C}$.

В группе технических сортов высокую морозоустойчивость показал сорт Альминский - минус $26^{\circ} \mathrm{C}$ при полной сохранности глазков и Алине побегов после прорастания значительно выше среднего показателя - 9,03-9,25 см. Также подтверждены данные полевых наблюдений о высокой устойчивости к морозу сорта Первенец Магарача - минус $24^{\circ} \mathrm{C}$, при сохранности глазков до $89 \%$, и минус $25^{\circ} \mathrm{C}$, при сохранности глазков до $33,3 \%$.

В группе элитных форм, полученных в результате целенаправленной селекции на улучшение автохтонных сортов Крыма по комплексу признаков, наиболее высокую устойчивость к максимацьным температурам показац межвидовой гибрид Магарач № 8-08-8-4 (Кок пандас х Зейбемь 6357), который при температуре минус $27^{\circ} \mathrm{C}$ обеспечивает прорастание побегов из замещающих почек на уровне $66,7 \%$, и при температуре минус $26^{\circ} \mathrm{C}-50$ $\%$ из центральной почки (рис. 2).

Отмечена средняя степень устойчивости у морозу у гибридной формы Магарач № 7-08-15-3 (Сары панАас 

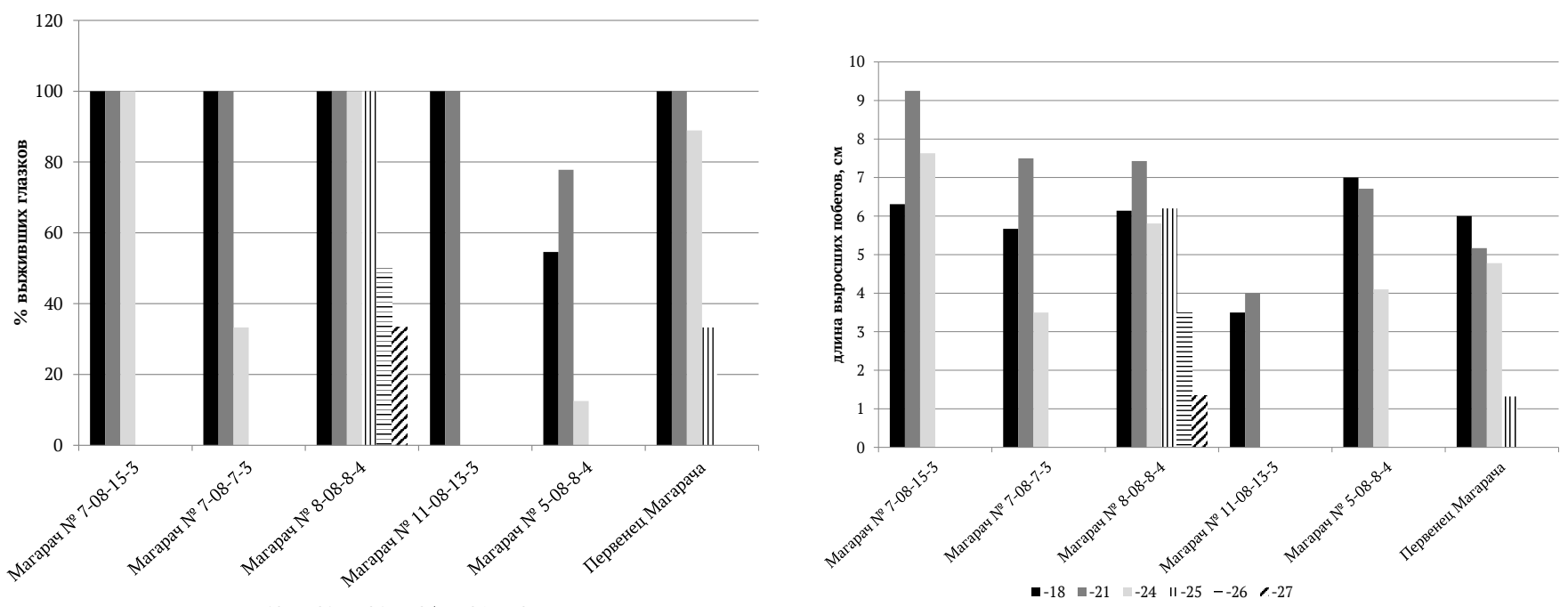

Рис. 1. Процент выживших глазков и длина выросших побегов у бессемянных сортов винограда при различных температурах промораживания лозы

Fig. 1. Percentage of survived eyes and the length of grown shoots on seedless grapevine cultivars under various vine freezing temperatures
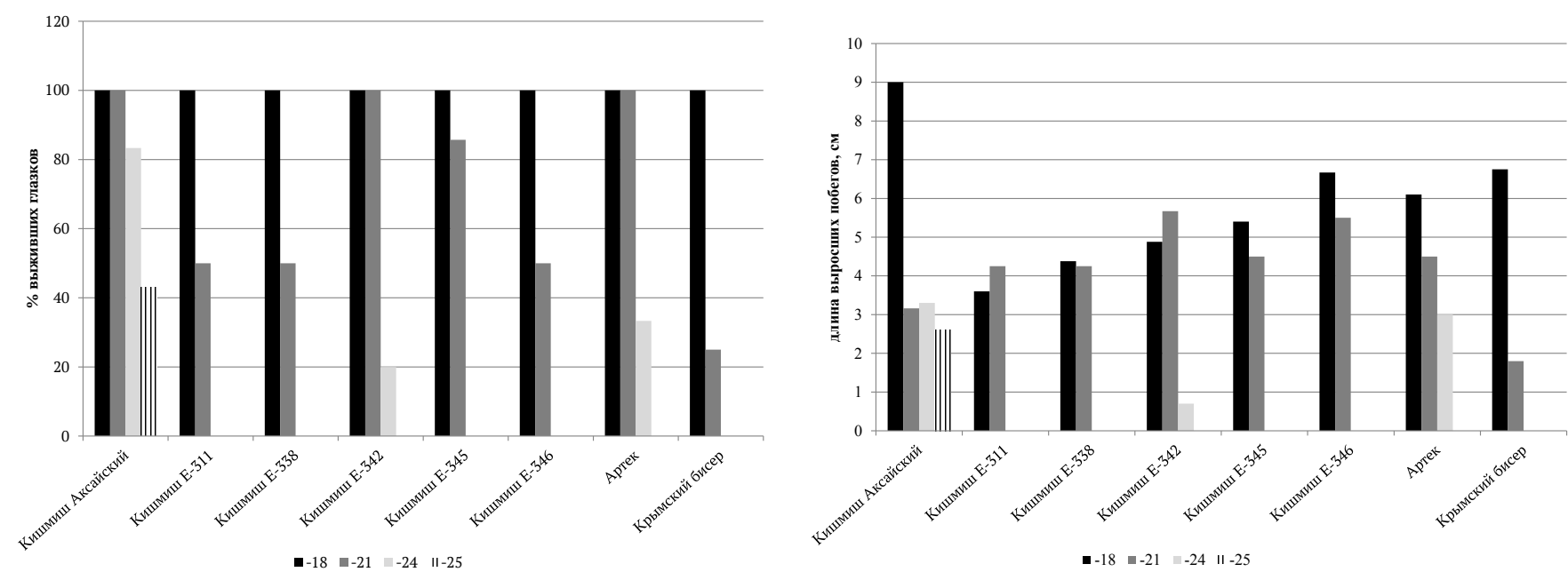

Рис. 2. Процент выживших глазков и длина выросших побегов у новых гибридных форм при различных температурах промораживания лозы

Fig. 2. Percentage of survived eyes and the length of grown shoots on new hybrid forms under various vine freezing temperatures

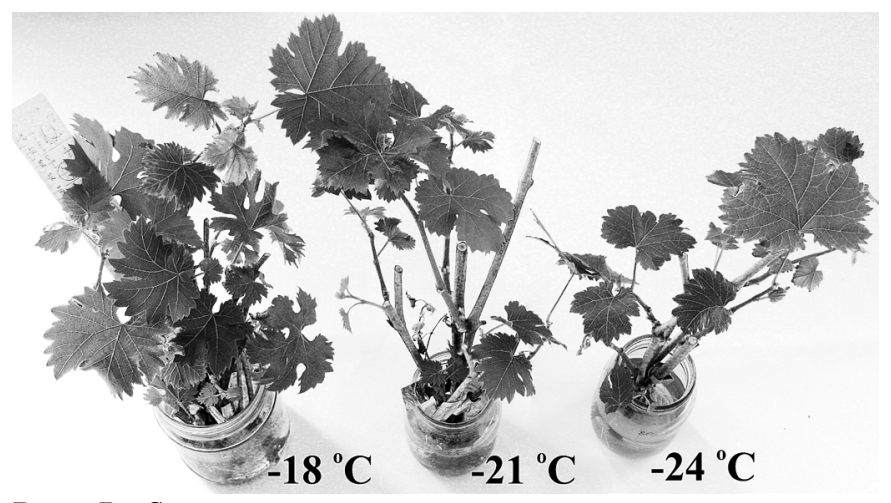

Рис. 3. Степень прорастания глазков и длина проросших побегов у гибридной формы Магарач № 7-08-15-3 (Сары пандас х Цитронный Магарача)

Fig. 3. The level of bud sprouting and sprout length of the hybrid form Magarach № 7-08-15-3 ('Sary pandas' x 'Tsitronnyi Magaracha')

х Цитронный Магарача), на уровне минус $24^{\circ} \mathrm{C}$, при сохранности глазков $100 \%$ (рис.3). Гибридная форма Магарач № 7-08-15-5 по Алине выросших побегов при температуре минус $21^{\circ} \mathrm{C}$ и минус $24^{\circ} \mathrm{C}$ достоверно превышает новые гибридные формы и контрольный сорт Первенец Магарача.

Наименьшую устойчивость среди изучаемых гибриАных форм в этой группе показац Магарач № 11-08-13-3 (Кок Пандас х Спартанец Магарача) - минус $21^{\circ} \mathrm{C}$, при $100 \%$ сохранности глазков. ОАнако Алина выросших побегов была минимальной - около 4 см, и существенно от$\Lambda$ ичацась от всех изучаемых гибридов.

В исследования вкмючены 12 гибридных форм, полученных на основе межвидовых скрещиваний [13]. Среди изучаемых выделены Ава перспективных гибрида с морозоустойчивостью минус $27^{\circ} \mathrm{C}$ : Магарач № 512-243-1 (сеянец Феркаць св. оп. х №52 Аанко) и Магарач № 530 (рис. 4).Эти гибридные формы вкцючены в Аальнейший селекционный процесс.

Выводы. В группе технических сортов высокую морозоустойчивость показац сорт Ацьминский - минус $26^{\circ} \mathrm{C}$ при полной сохранности глазков. В качестве ис-

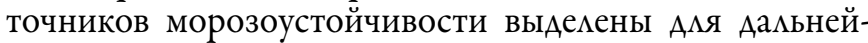
шей семекционной работы гибриА Магарач № 8-10-20-2 (минус $26^{\circ} \mathrm{C}$ ), Магарач № 530 (минус $27^{\circ} \mathrm{C}$ ) и Магарач № 512-243-1 (минус $27^{\circ} \mathrm{C}$ ). Перспективным гибридом 

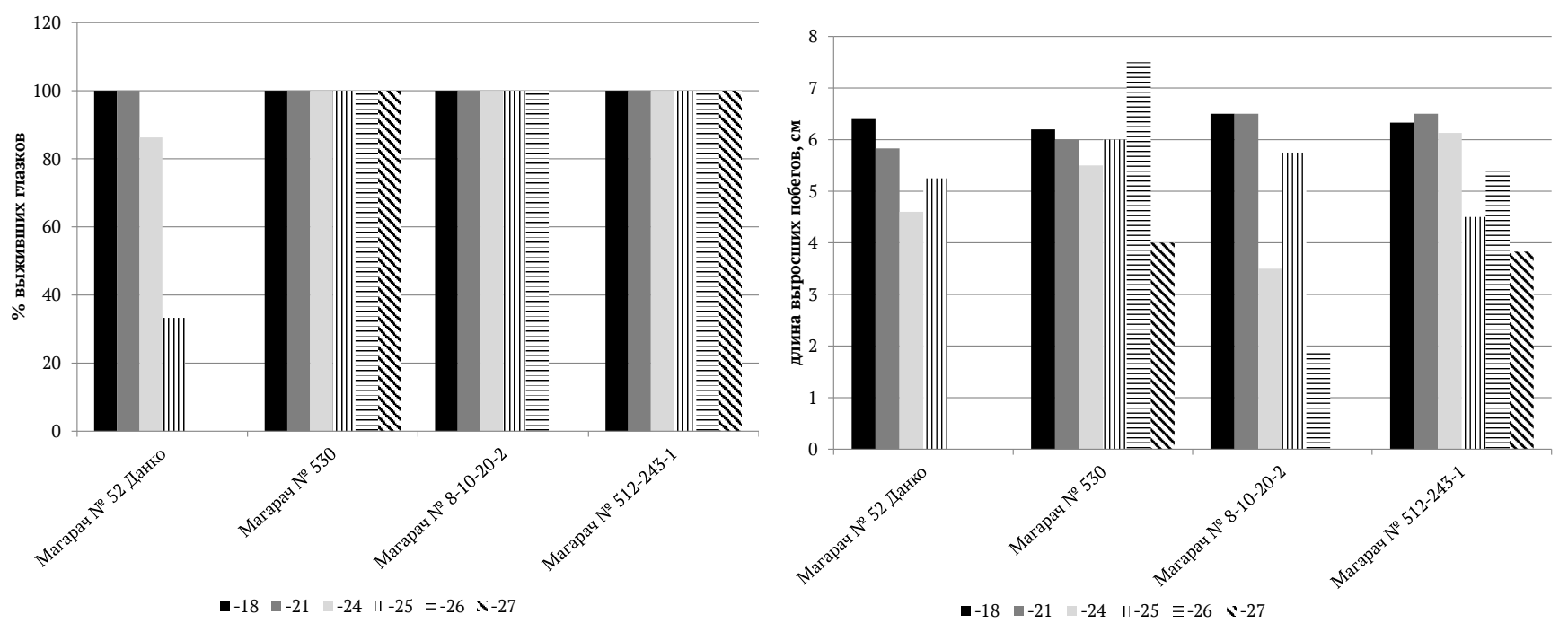

Рис. 4. Процент выживших глазков и длина выросших побегов у гибридов сложной генетической структуры при различных температурах промораживания лозы

Fig. 4. Percentage of survived eyes and the length of grown shoots of hybrids with complex genetic structure under various cane freezing temperatures

в группе устойчивых стац Магарач № 8-08-8-4 (Кок Пандас х Зейбель 6357), который при температуре минус $27^{\circ} \mathrm{C}$ обеспечивает прорастание побегов на уровне $66,7 \%$. Среди столовых бессемянных гибридных форм в качестве перспективного выдемен Артек, устойчивость которого к морозу отмечена на уровне минус $24^{\circ} \mathrm{C}$ при сохранности глазков 33,3\%.

\section{Источники финансирования:}

Исследования выполнены согласно ГЗ № 0833-20190006.

\section{Finansing source:}

The work was conducted under public assignment №0833-2019-0006.

\section{Конфликт интересов Не заяв $и$ ен.}

\section{Conflict of interests}

Not declared.

\section{Список литературы/ References}

1. Ненько Н.И., Ильина И.А., Петров В.С., Кудряшова В.В., Запорожец Н.М., Схаляхо Т.В. О формировании адаптационной устойчивости у растений винограда в осенне-зимний период // Сельскохозяйственная биология. - 2014. - Т. 49, № 3. - С. 92-99.

[Nenko N.I., Ilyina I.A, Petrov V.S., Kudryashova V.V., Zaporozhets N.M., Skhalyakho T.V. About grape plant adaptation to autumn and wintering. Sel'skohozyaistvennaya biologiya [Agricultural biology\}. 2014. V. 49, № 3. pp. 92-99. (in Russian)]

2. Майстренко А.Н., Майстренко Л.А. Состояние виноградников после зимы 2005-2006 гг. и морозоустойчивость сортов винограда // Плодоводство и ягодоводство России. 2006. - Т. 16. - С. 216-223.

[Maistrenko A.N., Maistrenko L.A. Sostoyaniye vinogradnikov posle zimy 2005-2006 gg. i morozoustoichivost' sortov vinograda [The state of vineyards after the winter of 20052006 and frost resistance of grape varieties]. Plodovodstvo $i$ yagodovodstvo Rossii $=$ Fruit growing and berry growing in Russia . 2006. T. 16. pp. 216-223. (in Russian)]

3. Носульчак B.А. Морозоустойчивость новых интродуцентов винограда // Виноделие и виноградарство. - 2008. - № 2. - C. 36-39.

[Nosulchak V.A. Morozoustoichivost' novyh introdutsentov vino- grada [Frost resistance of new grape introducers]. Winemaking and Viticulture. 2008. № 2. pp. 36-39. (in Russian)]

4. Xiaoyan Li, Lianguo Li, Jinyin [et al.] Introduction experiment of the cold resistant wine grape cultivar 'Frontenac'. Acta Hortic. 2015. V.1082. pp. 61-62. DOI: 10.17660. Acta Hortic. 2015. 1082. 6 .

5. Ласкавый В.Н., Кузьменко Е.Р., Гетьман Н.Г., Шабурова И.И. Оценка зимостойкости новых технических сортов винограда в условиях Запорожья // «Магарач». Виноградарство и виноделие. - 2018. - № 4. - С.45-46.

[Laskavyi V.N., Kuz'menko E.R., Get'man N.G., Shaburova I.I. Frost resistance assessment of new winemaking varieties of grapes in the condiions of Zaporozhye. Magarach. Viticulture and Winemaking. 2018. №4. pp.45-46. (in Russian)]

6. Ильяшенко О.М., Панкин М.И., Коваленко А.Г., Большаков В.А., Петров В.С. Адаптивность сортов винограда в условиях зимнего низкотемпературного стресса // Виноделие и виноградарство. - 2010. - № 6. - С. 33-35.

[Iljashenko O. M., Pankin M.I., Kovalenko A.G., Bolshakov V.A., Petrov V.S. Adaptability of grades of grapes in the conditions of winter low temperature stress. Winemaking and Viticulture. 2010. № 6. pp. 33-35. (in Russian)]

7. Волынкин В.А., Зленко В.А., Олейников Н.П., Лиховской В.В., Модонкаева А.Э Морозоустойчивость генетически разнородного генофонда винограда различных ботанических таксонов // «Магарач». Виноградарство и виноделие. - 2012. - № 1. - C. 2-4.

[Volynkin V.A., Zlenko V.A., Oleinikov N.P.1, Likhovskoy V.V., Modonkayeva A.E. Frost resistance of genetically diverse grape genofond belonging to didderent botanical taxons. Magarach. Vinogradarstvo $i$ vinodeliye $=$ Magarach. Viticulture and Winemaking. 2012. № 1. pp. 2-4. (in Russian)]

8. Новикова Л.Ю., Наумова Л.Г. Регрессионный анализ зимостойкости сортов винограда Донской ампелографической коллекции им. Я.И. Потапенко // «Магарач». Виноградарство и виноделие. - 2018. - №4. - С.59-61.

[Novikova L.Y., Naumova L.G. [Regression analysis of winter hardiness of grape cultivars from Ya.I. Potapenko don ampelographic collection. Magarach. Vinogradarstvo $i$ vinodeliye $=$ Magarach. Viticulture and Winemaking. 2018. №4. pp.5961. (in Russian)]

9. Volynkin V., Polulyah A., Klimenko V. [et al.] Breeding for Ukrainian table grape varieties. Vitis. Journal of Grapevine Research. 2015. T. 54, Special Issue. pp. 157-158. 
10. Усатов В.Т., Киреева Л.К., Клименко В.П., Волынкин В.А. Выведение комплексноустойчивых сортов винограда по новой иммуноселекционной программе // Виноградарство и виноделие. - 1992. - № 1-2. - С. 23-31.

[Usatov V.T., Kireeva L.K., Klimenko V.P., Volynkin V.A. Vyvedeniye kompleksnoustoichivyh sortov vinograda po novoi immunoselektsionnoi programme. [The development of complex-resistant grape varieties according to the new immunoselection program]. Vinogradarstvo $i$ vinodeliye = Winemaking and Viticulture. 1992. № 1-2. pp. 23-31. (in Russian)]

11. Клименко В.П., Волынкин В.А., Трошин Л.П. Подбор исходных форм винограда // Аграрная наука. -1997. -№ 2. -C. 25-27.

[Klimenko V.P., Volynkin V.A., Troshin L.P. Podbor iskhodnyh form vinograda. [Selection of initial grape forms]. Agrarnaya nauka $=$ Agricultural science. 1997. № 2. pp. 25-27. (in Russian)]

12. Зармаев А.А. Спартанец Магарача - ценный сорт винограда для Чеченской республики // Вестник Чеченского государственного университета. - 2017. - № 2 (26). - С. 20-25.

[Zarmaev A.A. Spartanec Magaracha - valuable grape cultivar for Chechen republic. Vestnik Chechenskogo gosudarstvennogo universiteta $=$ Bulletin of the Chechen State University. 2017. № 2 (26). pp. 20-25. (in Russian)]

13. Лиховской В.В., Зленко В.А., Олейников Н.П. Новый исходный материал в селекции на морозоустойчивость // «Магарач». Виноградарство и виноделие. - 2014. - № 2. - C. 7-9.

[Likhovskoy V.V., Zlenko V.A., Oleinikov N.P. A new source material selection of grapes on frost. Magarach. Vinogradarstvo $\mathrm{i}$ vinodeliye $=$ Magarach. Viticulture and Winemaking. 2014. № 2. pp. 7-9. (in Russian)]

14. Vool E., Rätsep R. and Karp K. Effect of genotype on grape quality parameters in cool climate conditions. Acta Hortic. 2015. 1082. P. 353-358. DOI: 10.17660/ ActaHortic.2015.1082.495

15. Клименко В.П. Отбор гибридов и сортов винограда в степном Крыму // Виноградарство и виноделие. -2003 . -Т. 34. -C. 46-52.

[Klimenko V.P. Otbor gibridov $i$ sortov vinograda $v$ stepnom Krymu [Selection of hybrids and grape varieties in the steppe Crimea]. Vinogradarstvo $i$ vinodeliye $=$ Viticulture and Winemaking]. 2003. T. 34. pp. 46-52. (in Russian)]

16. Зленко В.А., Волынкин В.А., Васылык И.А. Морозоустойчивость новых сортов и гибридов винограда сложной генетической структуры // In Book: LUCRĂRI ŞTIINŢIFICE. - Chișinău, 2018. - V. 47 - P. 243-247.

[Zlenko V.A., Volynkin V.A., Vasylyk I.A. Frost-resistance of new grape varieties and hybrids of complex genetic structure. In Book: LUCRĂRI ŞTIINŢIFICE. Chişinău, 2018. V. 47 pp. 243-247. (in Russian)]

17. Улитин В.О., Нудьга Т.А., Петров В.С., Коваленко А.Г., Хмыров А.П., Щербаков С.В., Ларькина М.Д. Морозостойкость сортов винограда различного происхождения при модельном промораживании и в полевых условиях // Вклад фундаментальных исследований в развитие современной инновационной экономики Краснодарского края. - 2007. - C. 180-182.

[Ulitin V.O., Nudga T.A., Petrov V.S., Kovalenko A.G., Khmyrov A.P., Scherbakov S.V., Larkina M.D. Morozostoikost' sortov vinograda razlichnogo proiskhozhdeniya pri model'nom promorazhivanii $i v$ polevyh usloviyah [Frost resistance of grape varieties of various origin during model freezing and in the field]. Vklad fundamental'nyh issledovanii $v$ razvitiye sovremennoi innovatsionnoi ekonomiki Krasnodarskogo kraya
[The contribution of basic research to the development of the modern innovative economy of the Krasnodar Territory].

2007. pp. 180-182. (in Russian)]

18. Лиховской В.В., Зленко В.А., Волынкин В.А., Олейников Н.П., Полулях А.А., Васылык И.А., Трошин Л.П. Морозоустойчивость крымских аборигенных сортов винограда и их гибридов // Политематический сетевой электронный научный журнал Кубанского государственного аграрного университета. - 2016. - № 117. - С. 681-694.

[Lihovskoi V.V., Zlenko V.A., Volynkin V.A., Oleinikov N.P., Polulyah A.A., Vasylyk I.A., Troshin L.P. Morozoustoichivost' krymskih aborigennyh sortov vinograda $i$ ih gibridov [Frost tolerance of Crimean native grape varieties and their hybrids]. Politematicheskii setevoi elektronnyi nauchnyi zhurnal Kubanskogo gosudarstvennogo agrarnogo universiteta [Political Internet electronic scientific journal of the Kuban State Agrarian University] 2016. № 117. pp. 681-694. (in Russian)] 19. Зленко В.А., Лиховской В.В., Волынкин В.А., Васылык И.А., Полулях А.А. Выявление новых доноров морозоустойчивости при селекции столовых сортов винограда // Труды Кубанского государственного аграрного университета. - 2017. - № 67. - С. 135-140.

[Zlenko V.A., Likhovskoy V.V., Volynkin V.A., Vasylyk I.A., Polulyach A.A. Identification of new frost-resistancy donors during selection of table grape varieties. Trudy Kubanskogo gosudarstvennogo agrarnogo universiteta [Proceedings of the Kuban State Agrarian University]. 2017. № 67. pp. 135140. (in Russian)]

20. Погосян C.А. Методические указания по селекции винограда. - Ереван: Айастан, 1974. - 226 с.

[Pogosyan S.A. Metodicheskiye ukazaniya po selektsii vinograda [Guidelines for the selection of grapes]. Yerevan. Aiastan. 1974. 226 p.

21. Черноморец М.В. Устойчивость виноградного растения к низким температурам. - Кишинев: Картя Молдовеняскэ, 1985. - 190 c.

[CHernomorets M.V. Ustoichivost' vinogradnogo rasteniya $k$ nizkim temperaturam [Resistance of a grape plant to low temperatures. Kishinev]. Kartya Moldovenyaske. 1985. 190 p. (in Russian)]

ORCID ID:

Лиховской B.B. https://orcid.org/0000-0003-3879-0485 